\title{
COMPORTAMENTO DE TERRAS RARAS E OUTROS ELEMENTOS-TRAÇO EM SOLEIRAS E DERRAMES DA REGIÃO NORTE-NORDESTE DA PROVÍNCIA MAGMÁTICA DO PARANÁ
}

\author{
Eduardo Reis Viana Rocha Júnior \\ Orientador: Dra. Leila Soares Marques (IAG-USP) \\ 95 p. - Dissertação (Mestrado) - Defesa 15.05 .2006
}

RESUMO. Foram determinadas as concentrações de terras raras (La, Ce, Nd, Sm, Eu, Tb, Yb e Lu) e outros elementos-traço (Cs, Rb, Ba, U, Th, Ta, Hf, Co e Sc) em 51 amostras representativas de derrames e soleiras das regiões norte e nordeste da Província Magmática do Paraná, que ocorrem no norte do estado de São Paulo e no sul de Minas Gerais. 0 método utilizado para estas determinações foi a técnica de ativação com nêutrons térmicos e epitérmicos, seguida de espectrometria gama de alta resolução, que forneceu resultados com elevados níveis de precisão e de exatidão (geralmente com valores inferiores a 10\%), conforme atestado pelas concentrações determinadas no material geológico de referência JB-1. Os dados obtidos foram analisados conjuntamente com determinações de elementos maiores, menores e dos traços Sr, Y, Zr, Nb, Cr e Ni, realizadas por fluorescência de raios - X. As rochas investigadas são quimicamente representadas por basaltos toleíticos, andesi-basaltos toléiticos e lati-basaltos, enquanto as mais evoluídas ( $\mathrm{MgO}<3 \%$ ), que ocorrem de modo muito subordinado, são representadas por latitos e lati-andesitos, além de um riodacito. As rochas básicas ( $\mathrm{SiO}_{2}<55 \%$ e/ou $\mathrm{MgO}>3 \%$ ) são caracterizadas por apresentarem conteúdos de $\mathrm{TiO}_{2}$ maiores que $3 \%$, sendo que grande maioria possui fortes semelhanças com os magmas-tipo Pitanga, embora tenham sido encontrados alguns derrames, localizados no norte do estado de São Paulo, geoquimicamente semelhantes aos magmas-tipo Urubici (típicos do sul da província). Rochas básicas com concentrações de $\mathrm{TiO}_{2}$ entre $2 \%$ e $3 \%$ foram raramente encontradas, as quais representam equivalentes intrusivos de derrames Paranapanema. As rochas mais evoluídas só foram encontradas em soleiras e possuem características geoquímicas que indicam diferenciação a partir de magmas do tipo Pitanga. 0 comportamento de elementos maiores, menores e traços nas rochas intrusivas e extrusivas do tipo Pitanga, incluindo as mais diferenciadas, é compatível com um processo de evolução por cristalização fracionada envolvendo plagioclásios, clinopiroxênios e titano-magnetitas. A comparação entre derrames e soleiras do tipo Pitanga indica a atuação significativa de processos de diferenciação in situ nas rochas intrusivas, que causaram uma maior variabilidade composicional (soleiras: $\mathrm{MgO}$ entre 2,3\% e 6,4\%; derrames: $\mathrm{MgO}$ entre 3,2\% e 5,5\%). As rochas mais diferenciadas são também caracterizadas por anomalias positivas de európio, que sugerem o acúmulo de plagioclásio devido a esse processo de fracionamento. Os dados obtidos também reforçam que não houve participação significativa de componentes astenostéricos do tipo N-MORB, E-MORB e OIB na gênese das rochas básicas investigadas, as quais possuem grande similaridade geoquímica com os basaltos da Cadeia Rio Grande (sítio 516F) e Cadeia Walvis (sítio 525A), especialmente com os desta última, indicando o envolvimento do componente mantélico EMI.

ABSTRACT. It is presented the determination of rare earth ( $\mathrm{La}, \mathrm{Ce}, \mathrm{Nd}, \mathrm{Sm}, \mathrm{Eu}, \mathrm{Tb}, \mathrm{Yb}$ and $\mathrm{Lu}$ ) and other trace (Cs, Rb, Ba, U, Th, Ta, Hf, Co and Sc) element concentrations in 51 representative samples of flows and sills from northern and northeastern Paraná Magmatic Province, particularly those located at north of São Paulo State and south of Minas Gerais. The employed analytical method to those determinations was thermal and epithermal neutron activation analysis, followed by high resolution gamma ray spectrometry, which provided high precision and accuracy results (in general better than $10 \%$ ), as verified by determinations in the international geological reference material JB-1. The obtained results were integrated with major, minor and trace ( $\mathrm{Sr}, \mathrm{Y}, \mathrm{Zr}, \mathrm{Nb}, \mathrm{Cr}$ and Ni) elements determined by X-ray fluorescence. The investigated rocks are mainly represented by tholeiitic basalts, tholeiitic andesi-basalts and lati-basalts, with subordinate relatively evolved ( $\mathrm{MgO}<3 \mathrm{wt} \%$ ) lithotypes, which are represented by latites and lati-andesites, besides one rhyodacite. The basic rocks $\left(\mathrm{SiO}_{2}<55 \%\right.$ and/or $\mathrm{MgO}>3 \%$ ) are characterized by presenting $\mathrm{TiO}_{2}$ contents higher than $3 w t \%$, very similar to Pitanga magma-type, although some flows, located at northern São Paulo State, geochemically similar to Urubici magma-type (typical of southern Paraná) were also found. Basic rocks having $\mathrm{TiO}_{2}$ contents between 2 and $3 \mathrm{wt} \%$ were rarely encountered and represent intrusive equivalents of Paranapanema flows. The more evolved rocks were just found in sills and have geochemical characteristics that indicate differentiation from Pitanga magma-types. Major, minor and trace element behaviour of intrusive and extrusive rocks of Pitanga type, including those differentiated ones, is compatible with evolution by fractional crystallization of plagioclases, clinopyroxenes and titanium magnetites. The comparison between flows and sills of Pitanga type indicates the significant role of in situ differentiation in the genesis intrusive rocks, causing its larger compositional variability (sills: Mg0 between $2.3 \mathrm{and} 6.4 \mathrm{wt} \%$; flows: Mg0 between 3.2 and $5.5 \mathrm{wt} \%$ ). The most evolved rocks are also characterized by positive europium anomalies, which suggest plagioclase accumulation caused by such fractionation process. The obtained data also corroborate the lack of significant participation of N-MORB, E-MORB and OIB asthenospheric mantle components in the genesis of basic rocks, which present very close geochemical similarity with Rio Grande Rise (site 516F) and Walvis Ridge (site 525A) basalts, particularly with the last ones, indicating the involvement of EMI mantle component. 